JASEM ISSN 1119-8362

All rights reserved
Full-text Available Online at www.bioline.org.br/ja
J. Appl. Sci. Environ. Mgt. September, 2006

Vol. 10 (3) 97 - 102

\title{
The Changing Rainfall Pattern and Its Implication for Flood Frequency in Makurdi, Northern Nigeria
}

\author{
TEMI E. OLOGUNORISA; TOR TERSOO \\ Department of Geography, Faculty of Natural and Applied Sciences, \\ Nasarawa State University, Keffi, Nigeria.
}

\begin{abstract}
The study deals with analysis of recent changes in the characteristics of extreme rainfall and their implication for flood frequency in Makurdi. Data on extreme daily rainfall, evapotranspiration and flood occurrences were collected for analysis. The annual rainfall was analysed for trends using spearman rank correlation coefficient, annual rainfall variability analysed using standardized rainfall anomaly index while recurrence intervals were analysed using Gumbell Extreme probability theory. The results of the analysis show among other things that there was a remarkable continuous downward trend in annual rainfall amounts; that the period between 1996 and 2001 witnessed the highest frequencies of extreme rainfall events and flood frequencies; that major floods were associated with high recurrence intervals, and that the seasonality of flooding in Makurdi occurs between May and October. @JASEM
\end{abstract}

Increasing flood risk is now being recognized as the most important sectoral threat from climate change in most parts of the world. This has prompted public debate on the apparent increased frequency of extreme, and in particular, on perceived increases in rainfall intensities (Dyson, 2000). Several studies have adduced extreme rainfall to be the major cause of flood worldwide. Such studies includes Gobo (1988), McEwen (1989), Oriola (1994) Babatolu (1996); FEPA (1998), Fowler and Kilsby (2003) Odekunle (2001), and Ologunorisa (2001, 2004). Other studies have identified the characteristics of extreme rainfall that are associated with flood frequency to include duration, intensity, frequency, seasonality, variability, trend and fluctuation (Olaniran, 1983; Ologunorisa, 2001; Ologunorisa and Diagi, 2005).

In Nigeria, studies on rainfall and their implication for flood frequency have been restricted to the southern parts of Nigeria, little or no attempt has been made in the literature to study the implication of recent changes in rainfall pattern on flood frequency in northern Nigeria despite increase frequency of floods in this region, and this is where this study derives its relevance. The present study attempts to examine recent changes in rainfall pattern and its implication on flood frequency in a seasonally flooded town of Makurdi, northern Nigeria.

Study Area: Makurdi: Makurdi the administrative headquarter of Benue state, lies approximately between latitude $7^{0} 44^{1} \mathrm{~N}$ and longitude $8^{0} 54^{1} \mathrm{E}$. The town is located along the coast of the River Benue. The climatic condition in Makurdi is influenced by two air masses: the warm, moist south westerly air mass, and the warm, dry northeasterly air mass. The southwesterly airmass is a rain - bearing wind that brings about rainfall from the months of May to October. The dry northeasterly airmass blows over the region from November to April, thereby bringing about seasonal drought. The mean annual rainfall in Makurdi is about $1,290 \mathrm{~mm}$. (Akintola, 1986). Temperature in Makurdi is however, generally high throughout the year, with February and March as the hottest months. Temperature in Makurdi varies from a daily of $40^{\circ} \mathrm{C}$ and a maximum of $22.5^{\circ} \mathrm{C}$.

Makurdi town, like most other cities in the lower Benue valley is drained by the Benue River and its tributaries. Other minor rivers that drain the Makurdi town, and in turn empty their waters in the River Benue includes: Rivers Idye, Genebe, Urudu, Kpege and Kereke. Due to the general low relief of Makurdi, sizeable portions of the area is waterlogged and flooded during heavy rainstorm (FMWRRD, 1998).

\section{MATERIALS AND METHODS}

Data Collection and Analytical Techniques: The data used for this work are from secondary sources. These include data on rainfall, evapotranspiration, and flood occurrence in Makurdi town. The rainfall data used are of two types - annual rainfall and extreme daily rainfall. The annual rainfall data covered the period from 1927 to 2004, while the extreme daily rainfall data spanned 1979 to 2004. The evapotranspiration records are for the period 1979 - 2004. Information on flood occurrence for 1994, 2001 and 2004 floods was collected from local newspaper reports, and past history of flood occurrence in the study area were also sourced from the monographs of the Federal Environmental Protection Agency (FEPA). Records of annual rainfall in Makurdi were collected from the publication of Akintola (1986) and the Nigeria Meteorological Agency, Makurdi branch. The extreme daily rainfall and evapotraspiration data

*Correspondence: E-mail 
were obtained from the archives of Nigerian Meteorological Agency, Makurdi.

In terms of analysis, basic statistical techniques like computation of totals, means and standard deviations were used for preliminary treatment of the data. The annual rainfall trend was determined using spearman rank correlations. In order to determine the significance of the correlation coefficient, it was tested using the Student's $\mathrm{T}$ test statistic at $95 \%$ confidence level.

The Standardized Rainfall Anomaly Index (SAI) was used in the analysis of annual rainfall variability. The $\mathrm{SAI}$ is given as:

$$
S A I=\frac{X_{i}-X^{-}}{S D}
$$

Where $\mathrm{X}$ is annual rainfall total, $\mathrm{X}^{-}$is the mean of the entire series, and S.D is the standard deviation from the mean of the series.

The extreme daily rainfall characteristics that were analyzed in this study are magnitude - frequency, seasonality and duration. The Gumbel extreme value distribution was used to determine the magnitude and frequency of extreme rainfall and hence, the recurrence interval. The method of recurrence interval used in this study is usually employed in the description of probability of recurrence or incidence of extreme events (Dury, 1964; Lang, 1997; Versace and Ferrari, 1997). It is primarily concerned with prediction, such as the estimation of the magnitude of the daily, monthly and annual rainfall total likely to be exceeded on average, say, once during fifty years. Generally, there are two ways by which recurrence interval of rainfall data is carried out, namely: (a) partial series and (b) annual series analyses. The partial series involves the extraction of all values above a given magnitude from the record of daily rainfall over the years of study. The annual series on the other hand involves the selection of the maximum values occurring in each year. The more commonly employed method is the annual series and it was employed in this study to determined various return periods.
The procedures involve arranging the annual series in descending order of magnitude. The recurrence interval (RI) is determined thus:

$$
R I=\frac{N+I}{M}
$$

Where: $\mathrm{N}=$ number of events in the series; $\mathrm{M}=$ rank of individual event; and RI is return period expressed in years.

The rainfall values were then plotted against their recurrence intervals on Gumbel's probability paper, and a line of "best fit" on the scatter diagram was drawn as described by Dury (1964). The water budget graph was determined by superimposing monthly averages of evapotranspiration on monthly rainfall totals for 1979 - 2004. From this, the duration of flooding in the study area was determined, and this is the period when rainfall is in excess of evapotranspiration.

\section{RESULT AND DISCUSSION}

Annual Rainfall Trend in Makurdi; A trend analysis of the annual rainfall of Makurdi for the 77 - years period (1927 - 2004) was carried out by using the Spearman Rank Correlation Coefficient statistics. The annual rainfall trend over the study period was shown to have a negative correlation coefficient of 0.31 . The significance of the trend was tested by the student's T-test, and was found to be significant at 95 per cent confidence level. This is an indication that there is a downward trend in annual rainfall in Makurdi town, signifying decline in rainfall.

The rainfall series for the period $1927-2004$ was further broken into 20- years intervals (i.e 1927 1946, $1947-1967,1968-1988)$ and for a 16 - years period $(1989-2004)$ in order to depict short-time trends within the time series (see WHO, 1966, and Parthasarathy and Dhar, 1975). The results of the analyses are presented in Table 1.

Table 1: A summary of correlation coefficients of annual rainfall trends and significance at $95 \%$ level of confidence.

\begin{tabular}{lllll}
\hline Time Period & $\begin{array}{l}\text { Correlation } \\
\text { Coefficient }\end{array}$ & $\begin{array}{l}\text { Student's } \\
\text { "T" } \\
\text { Value }\end{array}$ & $\begin{array}{l}\text { Critical } \\
\text { Value }\end{array}$ & Result \\
\hline $1927-1946$ & -0.00 & -0.04 & 2.101 & Not significant \\
$1947-1967$ & 00.00 & 0.00 & 2.101 & Not significant \\
$1968-1988$ & -0.42 & -1.96 & 2.101 & Not significant \\
$1989-2004$ & -0.04 & -0.16 & 2.101 & Not significant \\
\hline
\end{tabular}


The results in Table 1 indicate that there is no much variation between the short-term annual rainfall trends and that of the entire time series (1927 2004). The period 1968 - 1988 indicated an appreciable rainfall decline when compared to the annual trend coefficient of -0.31 . The entire rainfall trend in Makurdi over the study period is shown not to be significant at 95 per cent level of confidence.

Annual Rainfall Fluctuation in Makurdi (1927 2004): An analysis of the annual rainfall fluctuation in Makurdi was achieved by 5 - year running mean (Fig. 1). In terms of actual annual rainfall totals, the wettest years in the period of record were 1933 (1891.9mm), 1963 (1757.4mm), 1947 (1750.4mm), $1955(1750.1 \mathrm{~m})$ and $1999(1617.1 \mathrm{~mm})$, and the driest years were, $1988(841.1 \mathrm{~mm}), 1958(849.3 \mathrm{~mm}), 1936$ (851.1mm), $1973(882.0 \mathrm{~mm})$ and 1983 (928.0mm).

When a five - year running mean was put through the annual total rainfall series, fluctuations involving increased annual rainfall totals were most prominent in the periods $1929-1932(1400.0 \mathrm{~mm}), 1945-1947$ (1350.0mm), 1961 - 1969 (1400.0mm) and $1995-$ 1999 (1350.0mm). Fluctuations involving decreased rainfall totals were also depicted at the period $1956-$ 1959, with the worst deviation from the mean in the period 1970 - 1995 (See Table 2a and b).

Table 2a: Period of Remarkable Deterioration in Rainfall for Makurdi (1927 - 2004).

\begin{tabular}{llllll}
\hline $\begin{array}{l}1^{\text {st }} \text { Remarkable } \\
\text { Deterioration }\end{array}$ & Duration & $\begin{array}{l}2^{\text {nd }} \\
\text { Remarkable } \\
\text { Deterioration }\end{array}$ & Duration & $\begin{array}{l}3^{\text {rd }} \text { Remarkable } \\
\text { Deterioration }\end{array}$ & Duration \\
\hline $1935-1938$ & 3 years & $1955-1960$ & 5 years & $1971-1995$ & 24 years \\
\hline
\end{tabular}

Table 2b: Periods of above Average Rainfall for Makurdi (1927 - 2004)

\begin{tabular}{|c|c|c|c|c|c|c|c|}
\hline $1^{\text {st }}$ & & $2^{\text {nd }}$ & & $3^{\text {rd }}$ & & $4^{\text {th }}$ & Duration \\
\hline Above & Duration & Above & Duration & Above & Duration & Above & \\
\hline Average & & Average & & Average & & Average & \\
\hline Rainfall & & Rainfall & & Rainfall & & Rainfall & \\
\hline $1928-1935$ & 7 years & $1944-1955$ & 11 years & $\begin{array}{l}1960 \\
1970\end{array}$ & 10 years & $\begin{array}{l}1966- \\
1999\end{array}$ & 3 years \\
\hline
\end{tabular}

Tables $2 \mathrm{a}$ and $2 \mathrm{~b}$ show that the period $1927-1970$ was characterized by more years of above average rainfall. The period 1971-1995 was however characterized by a continuous 24 - years period of below average rainfall, an indication that the climate of Makurdi may be becoming drier recently.

Annual Rainfall Variability in Makurdi: Figure 2 depict that Makurdi has passed through wet and dry sequences over the study period. This station does not exhibit persistence in the pattern of wet and dry conditions. The remarkably below long - term means were recorded in the period 1985 - 1996, with 1988 $(-1.9)$ as the year of highest negative deviation. It is apparent from figure 2 that the occurrence of wet years was more than the dry ones from 1927 to 1984. For the past 20 years (1985 - 2004), however, only the period 1996 - 1999 was marked by positive departures from the mean. These recent findings contradict the earlier study by Gobo (1988), who argued that for a long - term climatic trend prediction, it is difficult to conclude whether the climate of the study area is becoming progressively drier or wetter.

Magnitude - Frequency of Extreme Daily Rainfall in Makurdi: Table 3 shows the values of extreme daily rainfall and their recurrence interval in Makurdi between 1979 and 2004. The characteristic of the increases, the magnitude of rainfall events increase at a lesser rate until a point is reached where lengthening of recurrence interval will involve no increase in magnitude. From Table 2 for instance, it can be inferred that daily rainfall event of $149.3 \mathrm{~mm}$, which is the highest in the series, can be expected to occur once in every 27 years. Whereas, daily rainfall amount of $125.3 \mathrm{~mm}$, the second in magnitude, can be expected to occur in every 13.5 years. However, for extreme daily rainfall amounts of lesser magnitudes such as $51.3 \mathrm{~mm}$ and $45.2 \mathrm{~mm}$, their recurrence intervals are 1.08 and 1.04 years respectively. The expected recurrence intervals of the extreme daily rainfall magnitudes are depicted in figure 3 . 
Table 3: Magnitudes - Frequency of Extreme Daily Rainfall Events in Makurdi (1979 - 2004).

\begin{tabular}{cccc}
\hline Years & $\begin{array}{c}\text { Rainfall } \\
\text { Amount } \\
\text { (MM) }\end{array}$ & Rank & $\begin{array}{c}\text { Recurrence } \\
\text { Interval } \\
\text { (years) }\end{array}$ \\
\hline 2000 & 149.3 & 1 & 27.00 \\
1986 & 125.3 & 2 & 13.50 \\
1981 & 123.7 & 3 & 9.00 \\
1999 & 119.3 & 4 & 6.75 \\
2002 & 101.1 & 5 & 5.40 \\
1990 & 100.7 & 6 & 4.50 \\
1984 & 95.0 & 7 & 3.85 \\
1998 & 92.9 & 8 & 3.37 \\
1997 & 89.5 & 9 & 3.00 \\
1996 & 86.3 & 10 & 2.70 \\
1987 & 85.3 & 11 & 2.45 \\
1989 & 83.3 & 12 & 2.25 \\
1993 & 80.3 & 13 & 2.07 \\
1985 & 76.8 & 14 & 1.92 \\
1980 & 76.2 & 15 & 1.80 \\
1983 & 74.0 & 16 & 1.68 \\
1979 & 71.9 & 17 & 1.58 \\
1982 & 71.7 & 18 & 1.50 \\
1995 & 70.6 & 19 & 1.42 \\
1992 & 70.5 & 20 & 1.35 \\
2004 & 65.8 & 21 & 1.28 \\
1994 & 61.7 & 22 & 1.24 \\
1991 & 56.6 & 23 & 1.17 \\
2003 & 54.7 & 24 & 1.13 \\
2001 & 51.3 & 25 & 1.08 \\
1988 & 45.2 & 26 & 1.04 \\
\hline & & & \\
\hline
\end{tabular}

Since a high intensity rainfall is that event which exceeds 48mm/h (Lang, 1997 and Odekunle, 2001), a look at Table 2 reveals that, in the 26 years series, only one event does not qualify as high intensity rainfall event $(45.2 \mathrm{~mm}$ extreme daily rainfall event of 1988). The year 1988 has also been depicted in Fig. 1 as the driest years in the $1927-2004$ rainfall record of Makurdi.

Seasonality of Extreme Daily Rainfall in Markurdi: Analysis of the seasonality of extreme daily rainfall event shows that the month of August had the highest frequency of 10 events and a total percentage of 36.43 in the series (Table 4 and 5).

Table 5 also reveals that, although the month of June, July and September come next to August with five extreme rainfall events, the total amount of extreme rainfall received in July $(428.7 \mathrm{~mm})$ falls short of those of June and September, with total rainfall amounts of $466.2 \mathrm{~mm}$ and $445.1 \mathrm{~mm}$ received respectively. The least extreme rainfall event in the series is that of October 27, 1988, $(45.2 \mathrm{~mm})$.
Table 4: Extreme Rainfall Series in Makurdi (1979 - 2004)

\begin{tabular}{|c|c|}
\hline Days & $\begin{array}{l}\text { Extreme } \\
\text { Rainfall } \\
\text { Amount } \\
(\mathrm{mm})\end{array}$ \\
\hline 20 August, 1979 & 71.9 \\
\hline 16 July, 1980 & 76.2 \\
\hline 20 July, 1981 & 123.7 \\
\hline 15 July, 1982 & 71.7 \\
\hline 5 June, 1983 & 74.0 \\
\hline 4 August, 1984 & 95.0 \\
\hline 15 July, 1985 & 76.8 \\
\hline 30 June, 1986 & 125.3 \\
\hline 22 August, 1987 & 85.3 \\
\hline 27 October, 1988 & 45.2 \\
\hline 18 September, 1989 & 83.3 \\
\hline 6 September, 1990 & 100.7 \\
\hline 27 August, 1991 & 56.6 \\
\hline 11 September, 1992 & 70.5 \\
\hline 10 July, 1993 & 80.3 \\
\hline 22 August, 1994 & 61.7 \\
\hline 13 August, 1995 & 70.6 \\
\hline 29 August, 1996 & 86.3 \\
\hline 7 September, 1997 & 89.5 \\
\hline 13 June, 1998 & 92.9 \\
\hline 25 June, 1999 & 119.3 \\
\hline 3 August, 2000 & 149.3 \\
\hline 2 August, 2001 & 51.3 \\
\hline 11 September, 2002 & 101.1 \\
\hline 7 June, 2003 & 54.7 \\
\hline 30 August, 2004 & 65.8 \\
\hline
\end{tabular}

Table 5: Seasonality of Extreme Rainfall in Makurdi

\begin{tabular}{lll}
\hline Month & $\begin{array}{l}\text { Frequency } \\
\text { (days) }\end{array}$ & $\begin{array}{l}\text { Percentage } \\
\text { of Total }\end{array}$ \\
\hline June & 05 & 21.39 \\
July & 05 & 19.67 \\
August & 10 & 36.43 \\
September & 05 & 20.43 \\
October & 01 & 2.01 \\
\hline
\end{tabular}


Frequency and Duration of Heavy Rainfall in Makurdi: For the ease of data collection, the frequency of rainfall intensities has been analyzed taking rainfall amounts of $<38.1 \mathrm{~mm}$ for light rainfalls $>38.1 \mathrm{~mm}$ and $<50.1 \mathrm{~mm}$ for moderate rainfall, and $>50.1 \mathrm{~mm}$ for heavy rainfalls (Figures 4,5 and 6).

Using the 25 years of record, mean annual frequency of 24 hour rainfall peaks of $<38.1 \mathrm{~mm},>38.1 \mathrm{~mm}$ $<50.1 \mathrm{~mm}$ and $>50.1 \mathrm{~mm}$ were 70,3 and 4 respectively. The number of peaks less than $38.1 \mathrm{~mm}$ in any year ranges between 90 (1992) and 46 (1983), while those $>38.1 \mathrm{~mm}<50.1 \mathrm{~mm}$ ranges between 9 (1980) and $1(1979 ; 1992 ; 2003)$. Heavy intensities of greater than $50.1 \mathrm{~mm}$ ranges from $9(1998 ; 1999)$ and zero (1988) (Fig. 6 ). The maximum recorded rainfall within the period of study was in 2000 with a 24 hour rainfall of $145.3 \mathrm{~mm}$ followed by $125.3 \mathrm{~mm}$ recorded in 1986 and $123.7 \mathrm{~mm}$ in 1981 .

Olaniran (1983) showed that heavy rains induce flooding when they occur about three or more times in a month during the period of moisture surplus. Based on this factor, the water budget graph of Makurdi was plotted using monthly totals of rainfall (mm) and evapotranpiration for the period 1979 2004 (Fig. 7). The water budget graph depicts the seasonal trend in soil moisture status. The month of August has been shown to have the highest moisture surplus. Excess soil moisture is however received from May to October, the period during which flooding is more likely to occur.

\section{Implication of Extreme Rainfall for Flood Frequency in Makurdi Town: Having examined some characteristics of extreme rainfall it becomes pertinent to assess the implications of such characteristics on flood frequency in the study area. Although McEwen (1989) employed a historic flood chronology data for a similar study, dearth of reliable flood chorology in the study area has necessitated the use of qualitative flood data as carried out by Babatolu (1996). The flood records used for this study were not defined in precise terms as peak over a constant threshold. Therefore, year-to-year correlation of rainfall and flood events was not possible}

From the analysis of rainfall magnitudes and estimated recurrence interval, it was found that available records of flood events corresponded to rainfall events of high recurrence intervals. For instance, the flood events of $25^{\text {th }}$ June $1999 ; 3^{\text {rd }}$ August 2000 and $11^{\text {th }}$ September 2002 corresponded to rainfalls with $6.7,27.0$ and 5.4 years recurrence intervals respectively. Major floods were mostly associated with high recurrence interval storms.

Temi E. Ologunorisa; Tor Tersoo
Although annual rainfall fluctuation in Makurdi was found to be in progressive decline (Fig. 1 and 2 ), the period 1996 to 2001 was marked by positive deviation from the mean. This period of positive deviation from the mean corresponded to periods of increased frequency of heavy rainfalls and flooding in the series (Fig. 6). This is in confirmation of the findings of Babatolu (1996), that heavy rainfall events are more likely to reflect annual changes than light or moderate falls. It therefore implies that it is these heavy rainfall events that result in overland flow and hence over bank flooding in Makurdi.

The seasonal trend in soil moisture status in Makurdi indicate that, the surplus water will first be utilized in recharging the underground moisture reserve from May and should be available for rapid run-off from August to October (Fig. 7). The month of August has been shown to be the month with the highest soil water surplus as well as having the most frequent events of extreme daily rainfall (Table 5) in the series. Thus, seasonality of extreme rainfall evidently had important implications for flood response. The recent flood records of $29^{\text {th }}$ August 1996 and $3^{\text {rd }}$ August 2000 are further indicators that floods are to be expected to occur mostly from August.

When data on days of extreme rainfall and flood incidences were crosschecked, there was a correlation. For instance, the flood events of $25^{\text {th }}$ June 1999; $3^{\text {rd }}$ August 2000 and $11^{\text {th }}$ September 2002 corresponded to days of extreme rainfall in the series. The recent devastating flood of $17^{\text {th }}$ July 2004 did not however correspond to the day of extreme rainfall for that year.

Conclusion: The results from this study reveal that there was a remarkable continuous downward trend in annual rainfall amounts in Makurdi from 1971 to 2004, breaking only from 1996 to 2001 . The period of recent upward trend (1996 - 2001) however recorded the highest frequencies of extreme rainfall events, with corresponding flood frequencies. It is also apparent from the analysis that Makurdi is getting drier, but receiving unprecedented heavy rainfalls. It is therefore, not the annual rainfall total that is an important cause of increased flood frequency in Makurdi but the percentage of it that falls as heavy falls.

\section{REFERENCES}

Akintola, F O (1986). Rainfall Distribution in Nigeria (1892 - 1983). Ibadan: Impact Publishers Nig. Ltd.

Ayoade, J O (1976). A Preliminary Study of the Magnitude, Frequency and Distribution of 
Intense Rainfall in Nigeria. Hydrological Science Bulletin, xxi, $419-427$.

Babatola, J S (1996). Recent Changes in Rainfall Patterns and its Implication for Flood Occurrence in Ondo, Nigeria. Ondo Journal of Arts and Social Sciences, 1 (1), pp. $125-136$.

Dury, G H (1964) Some Result of Magnitudes Frequency Analysis of Precipitation. Australian Geographical Studies, 4.1

Dyson, L L (2002). The Heavy Rainfall and Flood of February 2000: A Synoptic Overview of Southern Africa Floods of February 2000. Department of Civil Engineering, Pretoria: University of Pretoria.

Federal Ministry of Water Resources and Rural Development (FMWRRD). Managing Flood Problems in Nigeria, October, 1998.

Fowler, H J; Kilsby, C.G. (2003) Implications of Changes in Seasonal and Annual Extreme Rainfall. Geophysical Research Letters, 30 (13), pp. $17-20$.

Gobo, A E (1988). Relationship Between Rainfall Trends and Flooding in the Niger - Benue River Basin. The Journal of Meteorology, Vol. 13, No. 132, pp. $318-324$.

Lang, M (1997). New Development with AGREGEE. A Statistical Model using Hydrometeonelogical Information. FRIEND Project. H $-5-5$ (IHPIV).

McEwen, L J (1989). Extreme Rainfall and its Implication for Flood Frequency: A Case Study of the Middle River Tweed Basin, Scotland. Transactions of the Institute of British Geographers, Vol. 14, No. 3. pp. $287-298$.

Odekunle, T O (2001). The magnitude - Frequency Characteristic of Rainfall in Ondo, Southwestern Nigeria. Ife Research Publications in Geography, Vol. 8, pp. $36-41$.

Olaniran, O J (1983). Flood Generating Mechanism at Ilorin, Nigeria. GeoJournal,_7.3, pp. $271-27$.

Ologunorisa, E T (2001) An Assessment of Flood Risk in the Niger Delta, Nigeria. Unpublished Ph.D Thesis Department of Geography and Environmental Management, University of Port Harcourt, Port Harcourt, 303 pp.

Ologunorisa, E T (2004). Rainfall Flood Prediction in the Niger Delta, Nigeria (Abstract), International Conference in Hydrology: Science and Practice for the $21^{\text {st }}$ Century, London, U.K.

Ologunorisa, E T; Diagi, P N (2005). Extreme Rainfall and its Implication for Flood Frequency in the Western Niger Delta A Case Study of Warri. Nigerian Journal of Tropical Geography Vol. 1

Oriola, E O (1994). Strategies for Combating Urban Flooding in a Developing Nation: A Case Study of Ondo, Niger. The Environmentalist Vol. 14, pp. $57-62$.

Versace, P; Ferrari, E (1997). Regional Hierarchical Approach to Flood Frequency Analysis. FRIEND Project $\mathrm{H}-5-5-$ (IHPV). 